\title{
Record-High Specific Conductance and Water Temperature in San Francisco Bay during Water Year 2014
}

The U.S. Geological Survey (USGS) has operated a water-quality monitoring network in San Francisco Bay since the late 1980s (Buchanan and others, 2015). This network includes 19 stations in the bay; currently, 8 stations are in operation (fig. 1). All eight stations are equipped with specific-conductance (which can be related to salinity) and water-temperature sensors that record measurements at 15-minute intervals. Water quality in the bay constantly changes with the ocean tides and with seasonal and interannual differences in river inflows. Our network was designed to observe and characterize some of these changes in the bay across space and over time. Our data demonstrated a high degree of variability both in specific conductance and temperature at time scales from tidal to annual and also revealed longer term changes that are likely to influence overall environmental health in the bay.

In water year (WY) 2014 (October 1, 2013, through September 30, 2014), our network measured record-high values of specific conductance and water temperature at several stations during a period of very little freshwater inflow from the Sacramento-San Joaquin Delta and other tributaries because of severe drought conditions in California. This report summarizes our observations for WY2014 and compares them to previous years that had different levels of freshwater inflow.

\section{Instrumentation and Data Collection}

At each monitoring station, instruments were deployed by using a fixed mount at a constant elevation above the bottom; thus, the water depth above the sensors varied with the tides. At some stations, sensors were placed at two different elevations above the bottom (fig. 2). Sensors were cleaned and calibrated every few weeks, or as needed, during servicing trips. Sensor output is affected by biological growth, which usually increases over time and requires the affected data to

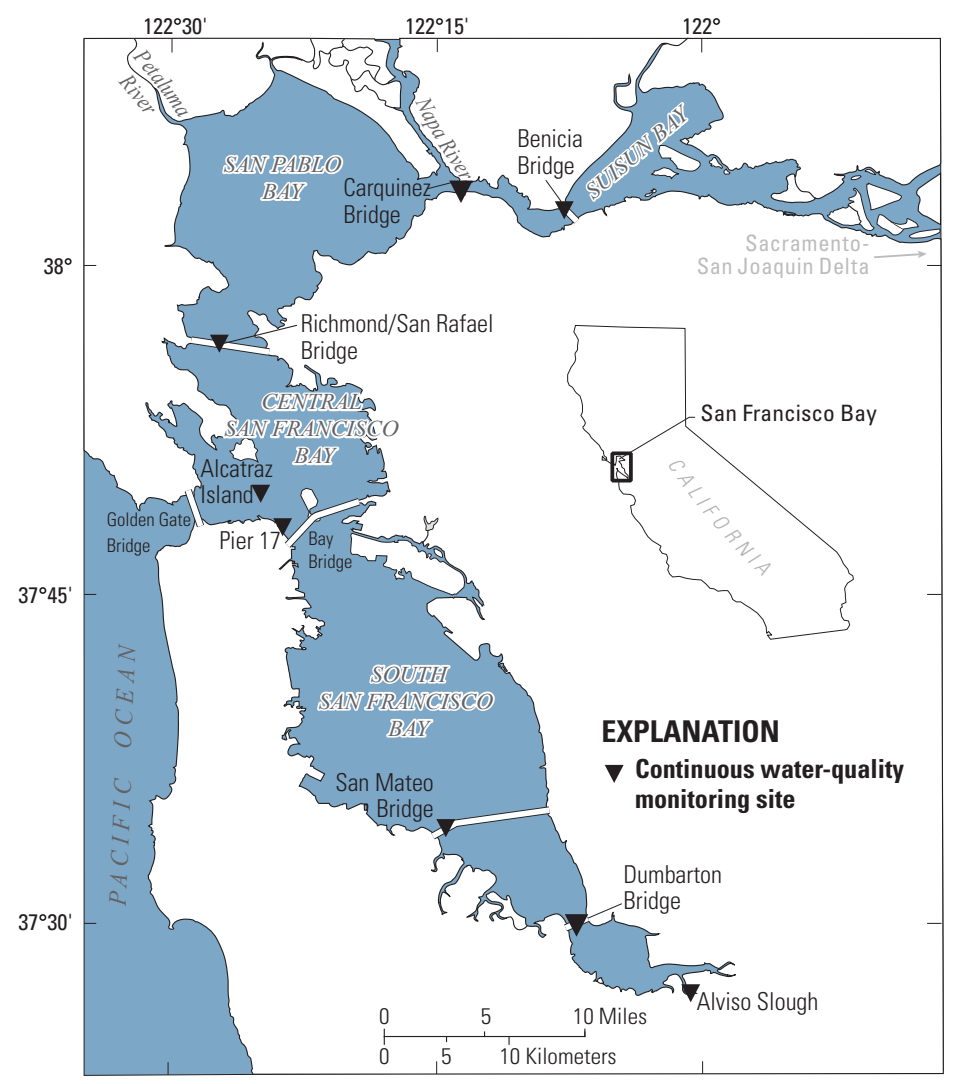

Figure 1. Locations of fixed water-quality monitoring stations in San Francisco Bay, California, for the 2014 water year (October 1, 2013 to September 30, 2014). be edited or deleted; other periods of missing data were caused by instrument failures or construction projects near the monitoring stations. Table 1 shows the scope of the dataset; all data are archived as provisional in nearreal time in the USGS National Water Information System (http://waterdata.usgs.gov/nwis) and undergo review before final approval. Further details on methods are available at http:/ca.water.usgs.gov/projects/baydelta/.

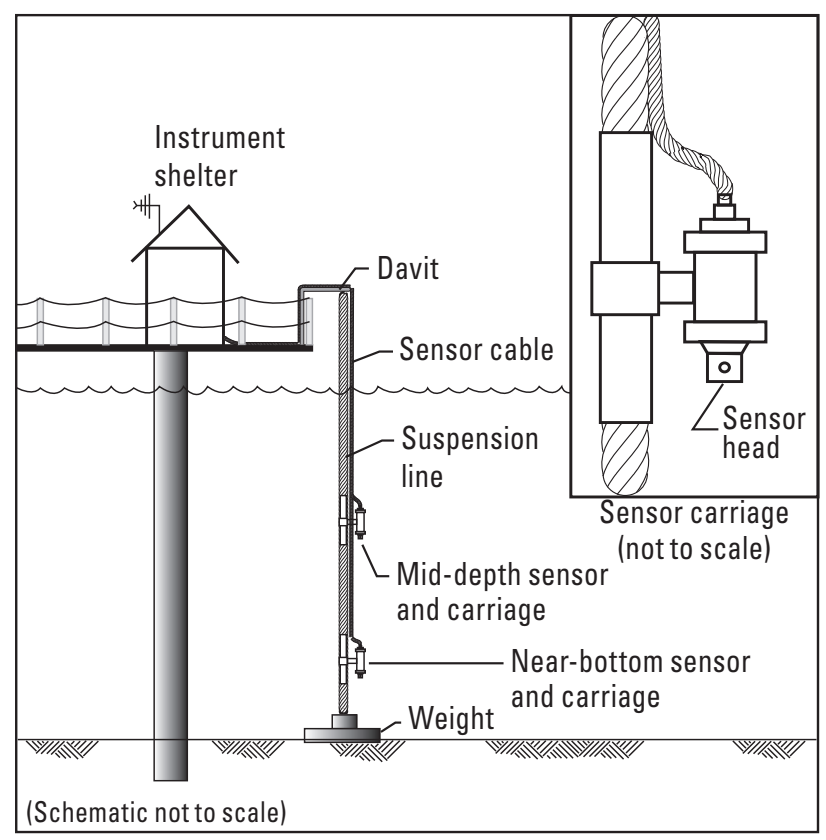

Figure 2. Typical monitoring-station installation. 
The instruments collected instantaneous measurements at 15-minute intervals, so the maximum number of data points for each monitored parameter was 96 per day or 35,040 per year. We determined annual-maximum values and computed annual-mean values for specific conductance and water temperature for each of our stations and compared results to those from previous years. To ensure that annual-mean values were representative despite missing data, the following thresholds were applied: if more than 33 percent of the data for a given year were missing, or if the duration of any one gap was longer than 45 consecutive days, the mean value for that year was not computed. Annualmean values were excluded for stations with less than 5 years of data (Alviso Slough, Dumbarton Bridge, and Pier 17, table 1). Salinity was computed according to the Practical Salinity Scale 1978 (Fofonoff and Millard, 1983) from measured specific conductance; values are unitless. Drought conditions affect water quality in the bay by reducing freshwater inflow from the watershed.

Table 1. Water-quality monitoring stations included in this report, listed from north to south.

["U" and "L" refer to the upper and lower sensor elevations in the water column, respectively, at stations equipped with two instruments. Station water depths are reported relative to mean lower low water.]

\begin{tabular}{|c|c|c|c|}
\hline Station name and number & $\begin{array}{l}\text { Water } \\
\text { depth, } \\
\text { in } \\
\text { meters }\end{array}$ & $\begin{array}{l}\text { Sensor } \\
\text { elevation } \\
\text { above } \\
\text { bottom, } \\
\text { in meters }\end{array}$ & $\begin{array}{c}\text { Year } \\
\text { monitoring } \\
\text { began }\end{array}$ \\
\hline $\begin{array}{l}\text { Suisun Bay at Benicia Bridge } \\
11455780\end{array}$ & 24 & $\begin{array}{r}23 \mathrm{U} \\
7.6 \mathrm{~L}\end{array}$ & 2001 \\
\hline $\begin{array}{l}\text { Carquinez Strait at } \\
\text { Carquinez Bridge }^{1} \\
11455820\end{array}$ & 24 & $\begin{array}{r}15 \mathrm{U} \\
1.8 \mathrm{~L}\end{array}$ & $1999^{1}$ \\
\hline $\begin{array}{l}\text { San Francisco Bay at } \\
\text { Richmond/San Rafael Bridge } \\
375607122264701\end{array}$ & 14 & $\begin{array}{l}9.1 \mathrm{U} \\
1.5 \mathrm{~L}\end{array}$ & 2006 \\
\hline $\begin{array}{l}\text { San Francisco Bay at } \\
\text { Alcatraz Island } \\
374938122251801\end{array}$ & 4.9 & 3.0 & 2003 \\
\hline $\begin{array}{l}\text { San Francisco Bay at Pier } 17 \\
374811122235001\end{array}$ & 8.5 & 1.2 & 2013 \\
\hline $\begin{array}{l}\text { San Francisco Bay at } \\
\text { San Mateo Bridge near } \\
\text { Foster City } \\
11162765\end{array}$ & 15 & $\begin{array}{r}13 \mathrm{U} \\
3.0 \mathrm{~L}\end{array}$ & 1990 \\
\hline $\begin{array}{l}\text { South San Francisco Bay at } \\
\text { Dumbarton Bridge }^{2} \\
373015122071000\end{array}$ & 14 & $\begin{array}{l}7.6 \mathrm{U} \\
1.2 \mathrm{~L}\end{array}$ & $2011^{2}$ \\
\hline $\begin{array}{l}\text { Alviso Slough near Alviso } \\
11169750\end{array}$ & 1.0 & 0.5 & 2010 \\
\hline
\end{tabular}

${ }^{1}$ Station temporarily discontinued during bridge construction June 10, 2012-April 23, 2014.

${ }^{2}$ Station temporarily discontinued during bridge construction October 1, 2011-March 16, 2013.
To explore the effects of differences in freshwater inflows and to compare WY2014 values to those from previous years, we estimated annual freshwater inflow volume from the delta with the Dayflow model (California Department of Water Resources, http://www.water.ca.gov/dayflow/). Output from this model includes the daily rate of freshwater flow from the delta to the bay, from which we calculated the annual volume of freshwater inflow from the delta. The annual volume of inflow from the delta is affected by hydrologic conditions and management actions, but is generally smaller during drought conditions and, thus, provides context for the severity of the current drought and its effect on water quality in the bay.

\section{Water Year 2014 Records}

During WY2014, our network measured instantaneous values of specific conductance and water temperature that exceeded all previously measured values at several stations. For specific conductance, record-high values were measured in WY2014 at Benicia Bridge, Carquinez Bridge, Richmond/San Rafael Bridge, San Mateo Bridge, Dumbarton Bridge, and Alviso Slough (fig. 3). Record-high water temperatures in WY2014 were measured at Carquinez Bridge, Richmond/San Rafael Bridge, Alcatraz Island, San Mateo Bridge, and Dumbarton Bridge (fig. 4).

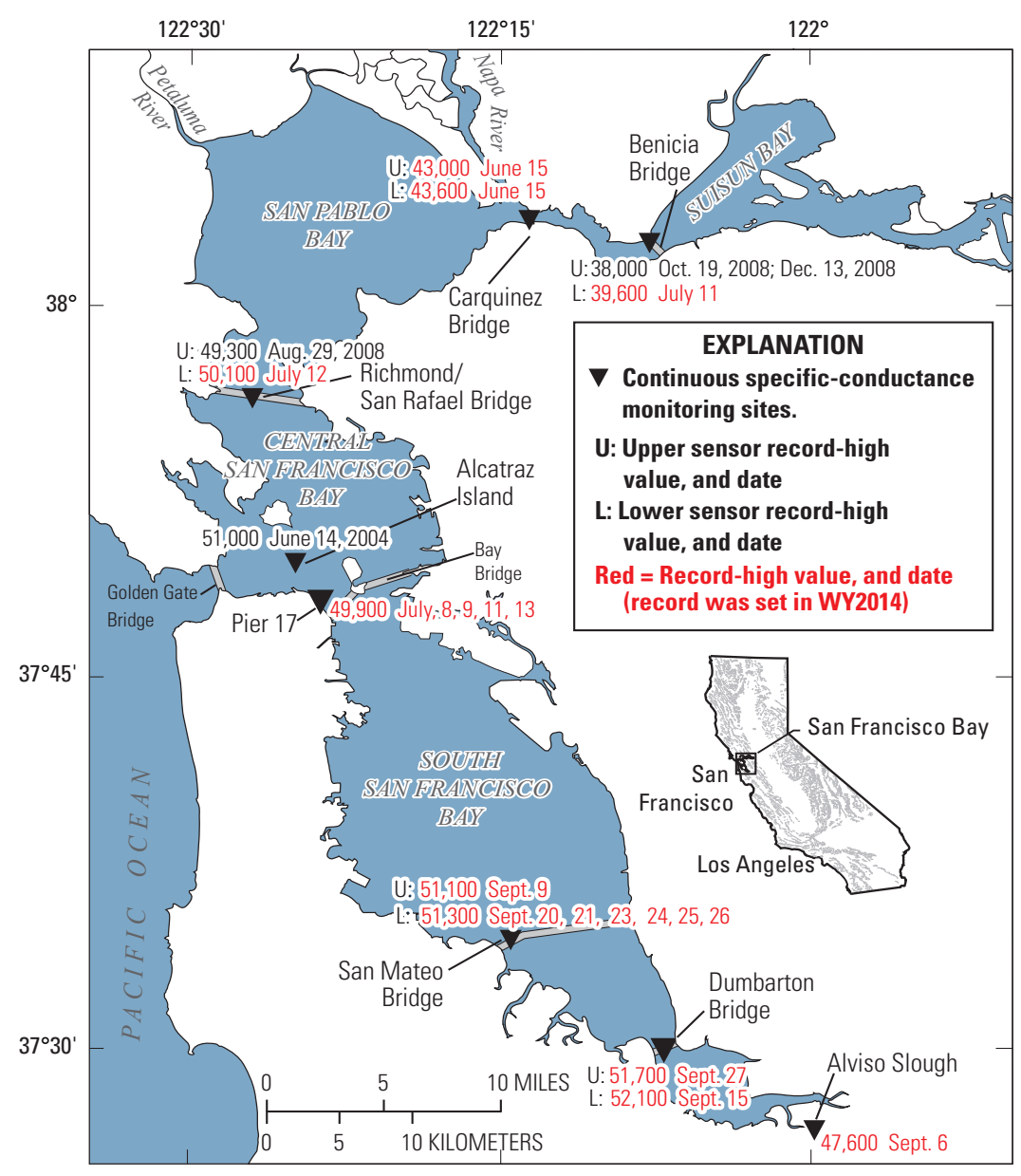

Figure 3. Maximum (record-high) instantaneous specific conductance from all data at each site sensor. Measured in microsiemens per centimeter. 


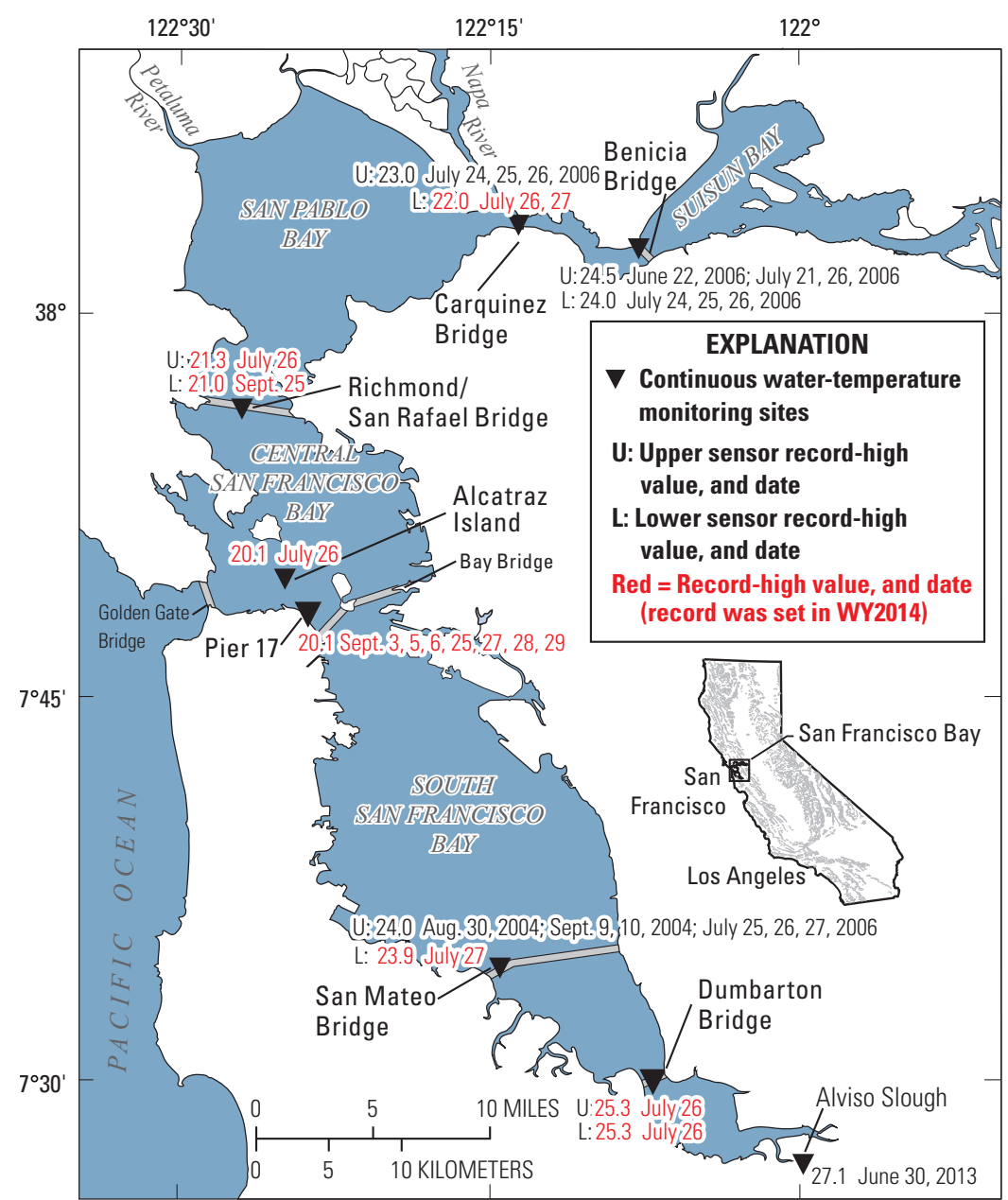

\section{Annual-Mean Values and Relation to Freshwater Inflow}

Annual-mean values of specific conductance and water temperature varied spatially as hydrologic conditions changed around the bay (fig. 5). Moving north and east from the ocean boundary (for example, Alcatraz Island, fig. 1) toward the delta, the major source of freshwater inflow (for example, Benicia Bridge, fig. 1), specific conductance generally decreased (fig. $5 A$ ), whereas water temperature generally increased (fig. $5 B$ ). Specific conductance in the southern region of the bay (San Mateo Bridge, fig. 1) was similar to that at the ocean boundary (fig. $5 \mathrm{~A}$ ), but water temperature was warmer than at the ocean boundary (fig. $5 B$ ). This was due, in part, to relatively little freshwater inflow from the adjacent watershed and to the relatively shallow water depths in the

For reference, specific conductances of 5,000 and 50,000 microsiemens per centimeter $(\mu \mathrm{S} / \mathrm{cm})$ at 25 degrees Celsius $\left({ }^{\circ} \mathrm{C}\right)$ are equivalent to salinities of 2.7 and 32.7, respectively. Specific conductance and salinity of freshwater are both near 0; coastal ocean water has a specific conductance of about $52,000 \mu \mathrm{S} / \mathrm{cm}$ at $25^{\circ} \mathrm{C}$ and a salinity of about 34 .

Figure 4. Maximum (record-high) instantaneous water temperature, from all data at each site sensor. Measured in degrees Celsius.

$\boldsymbol{A}$

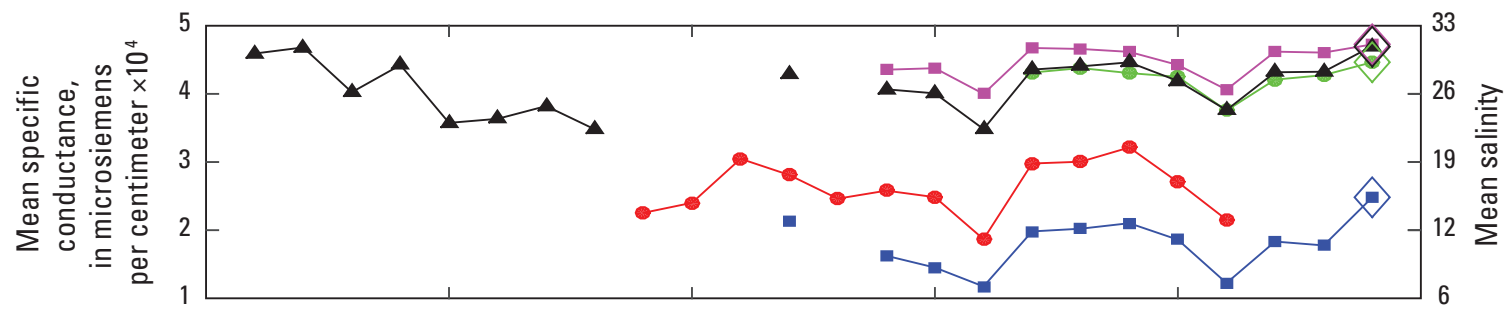

B

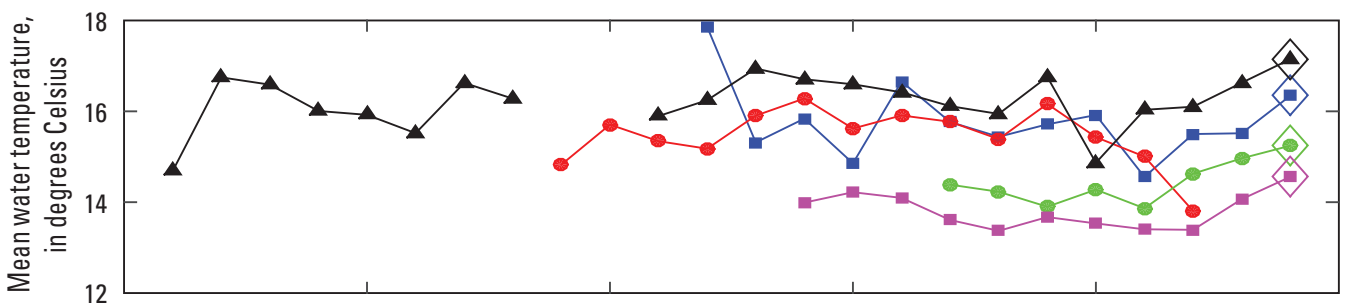

C

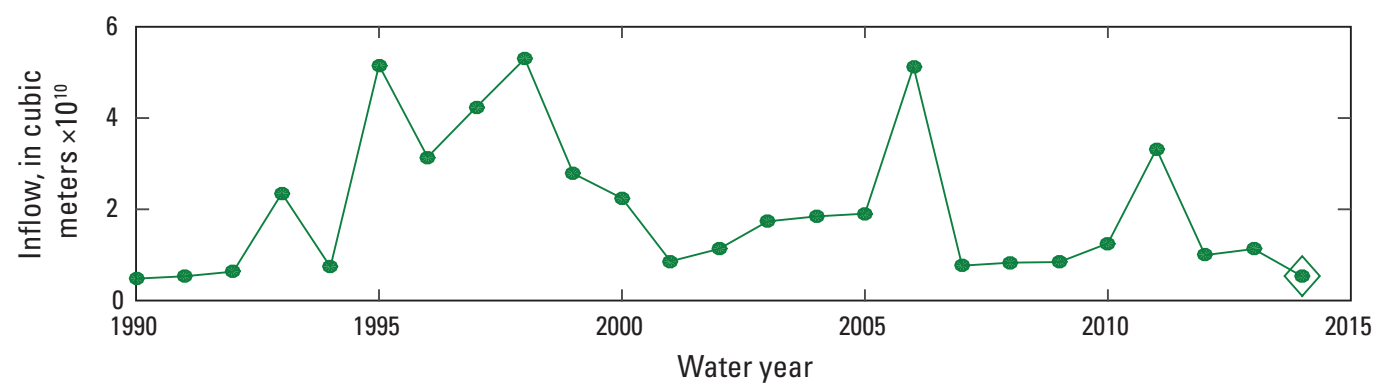

\section{EXPLANATION}

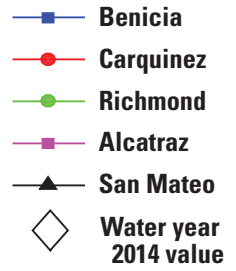

Figure 5. Mean annual values from 1990 to 2014; where two sensors were available, the upper sensor is shown: $A$, annual-mean specific conductance and salinity, by station; $B$, annual-mean water temperature, by station; and $C$, annual volume of freshwater inflow from the Sacramento-San Joaquin Delta to the San Francisco Bay, based on Dayflow model output. 
southern part of the bay. Variability in the annual volume of freshwater inflow from the delta was high (fig. 5C).

Of the four stations with sufficient WY2014 data to compute annual means, record-high annual-mean specific conductance and water temperature values were measured at four (fig. 5A) and three (fig. $5 B$ ) of the stations, respectively. Variability in annual-mean specific conductance can be partially attributed to variability in the annual volume of freshwater inflow from the delta (fig. 6), which affects flushing rates across the bay (Walters and others, 1985). For all stations, annual-mean specific conductance and the annual volume of inflow from the delta were inversely related, such that lower inflow volumes were associated with greater annual-mean specific conductance values (fig. 6). Stations farthest from the major source of freshwater inflow (Alcatraz Island, Richmond Bridge, and San Mateo Bridge, fig. 1) converged to nearly equivalent, high, mean specific-conductance values during the lowest inflow volumes, indicating that the bay is more influenced by coastal ocean waters during drought, when freshwater inflows from the delta are low.

Water temperature and specific conductance are important to human and ecological issues in the bay (for example, Shellenbarger and Schoellhamer, 2011) and elsewhere. These two water-quality parameters partially determine the available habitat for estuarine organisms, so changing conditions can affect the distribution and abundance of plants and animals in the bay. Only consistent long-term monitoring can reveal trends resulting from changing hydrologic conditions and management actions, and from responses to disturbances such as the severe California drought that began in 2012 .

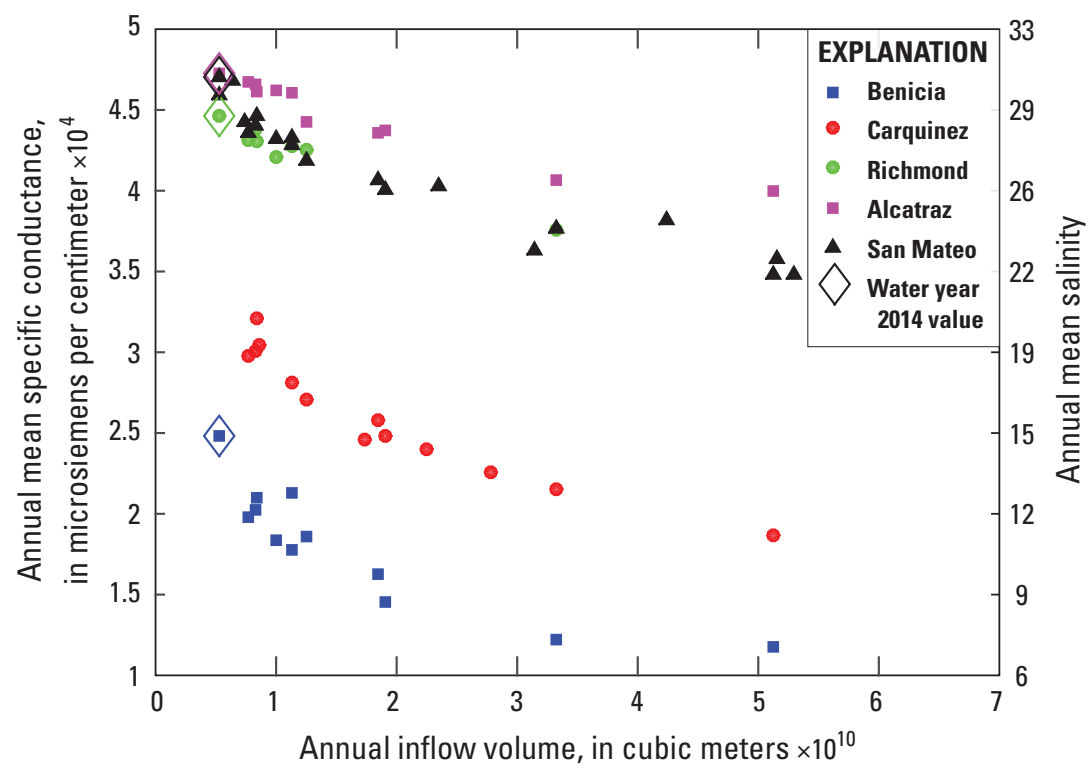

Figure 6. Annual means of specific conductance and salinity at each station as a function of annual volume of freshwater inflow from the Sacramento-San Joaquin Delta to the San Francisco Bay. For stations with two sensors (table 1), only the upper sensor is shown.

\section{References}

Buchanan, P.A., Downing-Kunz, M.A., Schoellhamer, D.H., Shellenbarger, G.G., and Weidich, K.W., 2014, Continuous water-quality and suspended-sediment transport monitoring in the San Francisco Bay, California, Water Years 2011-13: U.S. Geological Survey Fact Sheet 2014-3090, 4 p.

Fofonoff, N.P., and Millard, R.C., 1983, Algorithms for computation of fundamental properties of seawater: UNESCO Technical Papers in Marine Science, v. 44, p. 6-9.

Shellenbarger, G.G., and Schoellhamer, D.H., 2011, Continuous salinity and temperature data from San Francisco Estuary, 1982-2002: trends and salinity-freshwater inflow relationship: Journal of Coastal Research, v. 27, no. 6, p. 1191-1201.

Walters, R.A., Cheng, R.T., and Conomos, T.J., 1985, Time scales of circulation and mixing processes of San Francisco Bay waters: Hydrobiologia, v. 129, p. 13-36.

\section{Suggested citation}

Downing-Kunz, M.A., Work, P.A., and Shellenbarger, G.G., 2015, Record-high specific conductance and temperature in San Francisco Bay during water year 2014 (ver. 1.1, December 28, 2015): U.S. Geological Survey Open-File Report 2015-1213, 4 p.

\section{Acknowledgements}

Collection of these data was supported by the U.S. Army Corps of Engineers, San Francisco District, as part of the Regional Monitoring and Regional Sediment Management Programs; Interagency Ecological Program; California State Coastal Conservancy; U.S. Bureau of Reclamation; U.S. Geological Survey-San Francisco Bay Pilot Study for the National Water Quality Monitoring Network for U.S. Coastal Waters and their Tributaries; U.S. Geological Survey-Priority Ecosystems Science Program; and the U.S. Geological Survey Cooperative Water Program.

\section{For additional information,}

visit http://ca.water.usgs.gov/projects/baydelta/ or contact

Maureen Downing-Kunz at mdowning-kunz@usgs.gov,

Paul Work at pwork@usgs.gov, or Greg Shellenbarger at gshellen@usgs.gov.

U.S. Geological Survey California Water Science Center 6000 J Street, Placer Hall Sacramento, CA 95819 